\title{
Green Belt Kedung Ombo Reservoir and Local Community Welfare
}

\author{
Yoto Widodo ${ }^{1}$, Joko Setyo Basuki ${ }^{2}$ \\ \{yotowdd.63@gmail.com ${ }^{1}$, jokosbasuki@yahoo.co.id ${ }^{2}$ \} \\ Universitas Veteran Bangun Nusantara, Sukoharjo, Indonesia ${ }^{12}$
}

\begin{abstract}
Kedung Ombo Reservoir is one of the reservoirs built by the government to improve community welfare. So that the reservoir can be utilized according to the plan, it is necessary to involve the community in the management of one part of the reservoir, it is the green belt. Based on this background, this study aims to map and empower poor communities around the Kedung Ombo Reservoir and provide assistance in the utilization and planting of green belts. The research location was in Boyolayar in Ngargosari and Sendangpalang in Ngargotirto, Sumberlawang District, Sragen Regency, Central Java Province. The method used is a survey method. From the results of the study showed, for the community in the two hamlets had long used the green belt as a place to grow crops, But the trees planted did not match what was expected by the Kedung Ombo Reservoir manager. Therefore, the community needs assistance to choose tree crops that are useful to strengthen the shoreline coastline, and the community gets the most out of planting trees in the green belt.
\end{abstract}

Keywords: Green Belt, Welfare, Local Communities

\section{Introduction}

In the records of the Ministry of Public Works and Housing, Indonesia currently has 323 reservoirs, dams, and reservoirs, of which 53 percent suffered damage that remains around 151 [1]. Damage to some reservoirs is caused by many factors such as having reached the age limit, natural conditions and so forth, but all of that still leads to human activity, especially for those who are located around the reservoir. Poverty experienced by the community around the reservoir causes them to see the reservoir as a potential object to increase household income without considering the greater loss if the reservoir is exploited according to their wishes.

Heryanto's research [2] conducted in the Lodan Rembang Village in Central Java shows that the cost of maintaining a reservoir requires a large amount of funds. Large funds in maintenance cause the budget to swell [3]. If we see a lot of human activities around the reservoir such as the existence of fish cages, illegal logging in the green belt (green belt), disposal of various industrial and household waste and even rice fields become an inseparable part of the poor-local community with the reservoir [4]. The construction of the Linshui Reservoir of the Dahonghe Reservoir in Sichuan Province, which was built in the 1950-1970s, left many social and economic problems, especially for people who live around the reservoir. The results showed that some people changed their land use, especially in lowland areas that were inundated by reservoir water, while other people migrated. There 
were $35.27 \%$ of the population living below the poverty line. The eco-environment in the Linshui Reservoir Area is worse, and the eco-environment is less healthy.[5].

Based on this description, it seems that the involvement of the surrounding community needs to be prioritized if they do not want additional social or economic costs. For the government itself, by involving the community around the reservoir, the extra costs can be reduced automatically. While the local community will be able to provide additional income that has been insufficient or insufficient. On a large scale the community can gradually be alleviated from poverty. The purpose of this study is to map and empower poor communities around the Kedung Ombo Reservoir and provide assistance to them in planting and utilizing green belts. And the use of reservoirs as water attractions.

Broadly speaking poverty can be seen from two perspectives, namely economic perspective and social perspective. The meaning of economic perspective poverty, among others; limited income, low education and poor standard of living. The meaning of poverty is seen from a social perspective, poverty will result in the emergence of social inequality. The existence of social inequality will trigger social conflict. Various kinds of social ills can arise, such as crime, prostitution and vertical conflicts as well as horizontal conflicts.[6]. In addition to income, employment, and wages issues, the ADB defines poverty also regarding the lack of access to basic education, health concerns, availability water and sanitation, and home ownership. However, in practice, the standard most widely used to define and measure poverty is the availability of foodstuffs and other basic needs [7]. There are many regions or countries whose people's welfare depends on natural conditions. In Sri Lankan the existence of mangrove forests is very helpful for the socio-economic life of the surrounding community, especially for the poor [8].

Green belt is a green open space dominated by plants that surround the dam. Serves to prevent erosion and pollution, so that reservoirs can live very long (usually over 50 years). While the intent and purpose of the green belt is to conserve ecological and sociological conditions [9]. Greenbelt play an important role to minimize erosion risk around the reservoir/dam. Existence of vegetation along this greenbelt should be protected from land conversion and other encroachment such bushfires, felling and or illegal mining [10]. Human activity is the main factor that accelerates soil erosion in reservoir areas (green belt). In the long-term human activities include excessive use and uncontrolled clearing of new land, accelerating soil erosion and creating serious environmental problems.[11]. In Kenya the green belt movement has been spearheaded by the Nobel Peace Prize Winner Wangari Maathai, since 1977 the movement has planted millions of trees in an effort to restore ecosystems, promote sustainable livelihoods, empower women and promote democracy[12].

\section{Research Method}

The method used in this study is a survey method, namely the exploratory method. Explorative research is open in nature, it is a development of the concept and collection of Singarimbun facts [13]. In this research combined quantitative and qualitative approaches, combining quantitative and qualitative approaches in understanding a reality gives better results, provides richer data, and is complementary [14][15]. This research was conducted in a residential area around the Kedung Ombo Reservoir, namely in Boyolayar, Ngargosari and Sendangpalang, Ngargotirto, Sumberlawang, Sragen, Central Java Province. The number of family heads as the population in Sendangpalang are 614 people, while the sample is set at 
$10 \%$ of the population, which is 61 people. For Boyolayar the population are 64 households, while the sample are 38 people, or 60 percent of the population.

\section{Results and Discussion}

Sendangpalang is one of the hamlets in the Ngargotirto area. More than $90 \%$ of the population work as sharecroppers. Some other residents work outside the area as laborers. Most farmers cultivate lands owned by the Ministry of Public Works, especially in the area of the green belt. Another part of the population cultivates on land owned by Perhutani, by way of rent, in the amount of IDR. 90,000 as long as Perhutani's land can be planted (about 3 years). The income of Ngargosari villagers is included in the low category, compared to other villages in Sumberlawang District. This is evident that, around $40 \%$ of Ngargotirto Village residents are recipients of rice for the poor. Boyolayar is one of the hamlets in the Ngargosari area. More than $90 \%$ of the population work as farmers, some farmers own land and some others work as farm laborers. The income of Ngargosari villagers is included in the low category compared to other villages in Sumberlawang. This is proven that around $45 \%$ of Ngargosari residents are recipients of rice for the poor. Their living conditions are not better than Ngargotirto Village.

\subsection{Age of Respondents}

Table 1. Age of Respondents

\begin{tabular}{cccccc}
\hline \multirow{2}{*}{ No. } & \multirow{2}{*}{ Ages } & \multicolumn{2}{c}{ Sendangpalang } & \multicolumn{2}{c}{ Boyolayar } \\
& & total & $\%$ & total & $\%$ \\
\hline 1 & $30-40$ & 8 & 13 & 15 & 39 \\
2 & $41-50$ & 19 & 31 & 9 & 24 \\
3 & $51-60$ & 17 & 28 & 8 & 21 \\
4 & $>60$ & 17 & 28 & 6 & 16 \\
& & 61 & 100 & 38 & 100 \\
\hline
\end{tabular}

From the processing of the results of the questionnaire it can be seen that the respondents in both hamlets, Sendangpalang and Boyolayar are none under the age of 30 years, even respondents over the age of 60 are quite a lot. In Sendangpalang, respondents aged over 60 years accounted for $28 \%$, while in Boyolayar there were $16 \%$. This shows the habits of the villagers who worked hard since they were young have formed their bodies to be strong and not easily consumed by age. For young people under the age of 30 , they prefer to migrate to work in the city.

\subsection{Education Level of Respondents}

In terms of education, the education level of respondents in Boyolayar and Sendangpalang are low. As many as $97 \%$ of Sendangpalang respondents only completed primary school education, even the highest education was only junior high. Whereas in Boyolayar with $76 \%$ of elementary school education, the highest level of education is up to senior high school. There are no respondents in the two hamlets who have college level education. The education level of respondents can be seen in the table below.

Table 2. Respondent Education Levels

\begin{tabular}{|c|c|c|c|}
\hline $\mathrm{No}$ & Level & Sendangpalang & Boyolayar \\
\hline INO. & Education & total & total \\
\hline
\end{tabular}




\begin{tabular}{llllll}
\hline 1 & $\begin{array}{l}\text { Elementary } \\
\text { school }\end{array}$ & 59 & 97 & 29 & 76 \\
2 & JHS & 2 & 3 & 5 & 13 \\
3 & SHS & - & - & 4 & 11 \\
4 & Bachelor & - & - & - & - \\
& & 61 & 100 & 38 & 100 \\
\hline
\end{tabular}

Source: Primary Data (Questionnaire), 2016

From the data obtained it can be seen that when linked between age and education level, it can be said that the level of education in the two hamlets is low. Most of them have secondary education (JHS and Elementary School). It is less profitable for change and future community development. As it is known that people who have low levels of education find it difficult to accept innovations from outside. They require more time compared to people with high or middle education. Highly educated people can think more rationally and be open.

\subsection{Livelihood}

As with rural areas in Java in general, residents who live in villages are mostly livelihoods as farmers. Before the Kedung Ombo dam was built, the majority of residents of Boyolayar and Sendangpalang lived as farmers. Residents who do not own agricultural land they rent land owned by Perhutani. 97\% of Sendangpalang residents earn a living as farmers the remaining 3\% are fishermen. In Boyolayar the livelihoods of the population are more varied, the largest percentage remains as farmers $74 \%$, while the rest work as traders, fishermen and artisans. More about this can be seen in the following table.

Table 3. Respondents' Livelihoods

\begin{tabular}{|c|c|c|c|c|c|}
\hline \multirow{3}{*}{ No. } & \multirow{3}{*}{ Profession } & \multirow{2}{*}{\multicolumn{2}{|c|}{ Sendangpalang }} & \multirow{2}{*}{\multicolumn{2}{|c|}{ Boyolayar }} \\
\hline & & & & & \\
\hline & & total & $\%$ & total & $\%$ \\
\hline 1 & Farmers & 59 & 97 & 28 & 74 \\
\hline 2 & Fisherman & 2 & 3 & 6 & 16 \\
\hline 3 & Artisan & - & & 1 & 3 \\
\hline \multirow[t]{2}{*}{4} & Seller & - & & 3 & 7 \\
\hline & & 61 & 100 & 38 & 100 \\
\hline
\end{tabular}

Source: Primary Data (Questionnaire), 2016

\subsection{Respondents Income Level}

Kedung Ombo Reservoir construction is expected to have a positive impact on the welfare of the surrounding community. Especially the establishment of a cooperative relationship between local communities and Kedung Ombo Reservoir managers in managing green belts can increase community income. Reservoir construction in general will attract the attention of the public to come to see the existence of reservoirs.

Table 4. Respondents' Income

\begin{tabular}{llllll}
\hline No. & Income & \multicolumn{2}{l}{ Sendangpalang } & \multicolumn{2}{l}{ Boyolayar } \\
& & total & $\%$ & total & $\%$ \\
\hline 1 & $<500$ & 51 & 84 & 19 & 50 \\
2 & $>500-1,000$ & 8 & 13 & 7 & 18 \\
3 & $1,000-1500$ & 2 & 3 & 4 & 11
\end{tabular}




\begin{tabular}{llllll}
4 & $>1500-2000$ & - & - & 2 & 5 \\
5 & $>2000-2500$ & - & - & 3 & 8 \\
6 & $>2500-3000$ & - & - & 3 & 8 \\
& & 61 & 100 & 38 & 100 \\
\hline
\end{tabular}

Source: Primary Data (Questionnaire), 2016

The above table reinforces the previous statement that Ngargosari and Ngargotirto are two villages in Sumberlawang which are low income or poor. Respondents in the two villages, most of them earn below Rp.500,000, even in Sendangpalang respondents who think under Rp.500,000, - there are $84 \%$. Whereas in Boyolayar, respondents who earn below Rp. 500,000, are 50\%.

\subsection{Extent of Respondent's Land Ownership}

Green Belt land ownership above means the green belt land used by the community to grow crops. According to Mr. Bayan Sendangpalang's speech, at the beginning the land ownership of the green belt of the community could work in accordance with the capabilities of each resident's power. Of the area of land that was cultivated for the first time, it has finally been considered as their own, in other words, residents are allowed to farm on the land but not as ownership rights. Therefore, it is not surprising if the ownership of land area between one resident and another varies.

Table 5. Ownership of Green Belts (Green Belt)

\begin{tabular}{llllll}
\hline No. & Income & \multicolumn{2}{l}{ Sendangpalang } & \multicolumn{2}{l}{ Boyolayar } \\
& & total & $\%$ & total & $\%$ \\
\hline 1 & $0.25 \mathrm{Ha}$ & 36 & 59 & 27 & 71 \\
2 & $0.5 \mathrm{ha}$ & 17 & 28 & 11 & 29 \\
3 & $0.75 \mathrm{Ha}$ & 2 & 3 & - & - \\
4 & $<1 \mathrm{Ha}$ & 6 & 10 & - & - \\
& & 61 & 100 & 38 & 100 \\
\hline
\end{tabular}

Source: Primary Data (Questionnaire), 2016

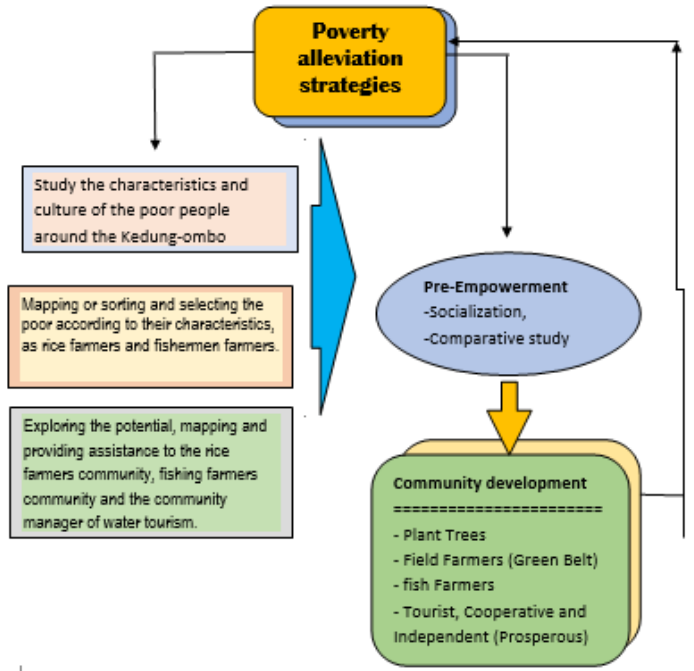

Fig 1. Poverty Alleviation Strategies 
Boyolayar, Ngargosari and Sendangpalang, Ngargotirto still adhere to ethical values and manners like the Javanese community in general. If there are behaviors of community members that are different from the habits of the local community, it will be considered as a despicable act. At a certain level people who commit social deviations will be ostracized and even driven out of the village. For poverty alleviation in rural areas that have a population (head of household) most of the age above 30 years, requires a special strategy. Such a society will have difficulty improving their education given their age.

The education needed by the community is in the form of training or adding practical skills or a kind of appropriate technology. They need help in the short term, currently they live in a condition that is lacking, therefore they need immediate assistance (emergency) that cannot be postponed for a long time. For this reason, researchers offer a simple strategy to tackle poverty, which can be used to alleviate poverty in the short term.

\section{Conclusions}

Based on the results of the study, the following conclusions can be drawn. The people of Ngargosari and Ngargotirto in general are still holding on to social values and customs. They still carry out ceremonies related to the cycle of human life from birth to death, customs related to the beginning of the planting period and the rice harvest period are called dekah deso or sedekah bumi. The traditional ceremonies are a means of guarding the integration of local communities. The community also respects community leaders and keeps the institutions in their village. As with rural communities in Indonesia in general, the Boyolayar, Ngargosari and Sendangpalang, Ngargotirto, the majority work as farmers. Most of the population grow crops on Perhutani's land and Green Belt land only a few grow on private land.

The existence of a green belt is a profitable land for the manager of the Kedung Ombo Reservoir and the community around the reservoir. For managers of Kedung Ombo Reservoir, the green belt can withstand landslides on the reservoir beach. For communities around the existence of the green belt can increase the area of ownership of agricultural land, so that it will be able to increase income and reduce poverty in local communities.

\section{References}

[1] Kedaulatan Rakyat, "Waduk PLTA Mrica Terancam Tamat; 71 Persen Volume Waduk Terisi Sedimem," Kedaulatan Rakyat, Apr. 2015.

[2] Y. Heryanto, "Pengembangan Penilaian Kondisi Fisik Bendungan untuk Penentun Penanganan Pemeliharaan Bendungan( Study Kasus: Waduk Lodan)," Jurnal Teknik Sipil Magister Teknik Sipil Universitas Sebelas Maret, vol. II, no. 1. pp. 89-99, 2014.

[3] Bisnis Indonesia, "Jika Relasi Tuntas, PU-Pera Akan Bangun 13 Waduk," Apr. 2015.

[4] Kompasiana, "Dinding Megah Jatilihur, Seberapa Banyakkah yang Mengenalnya." 2012.

[5] C. W. \& D. X. Jing-an Shao, Xue-qin Huang, Ming Qu, "Land use change and its socioeconomic driving forces under stress of project in old reservoir area," Sci. Rep., vol. 15, pp. 315-324, 2005, doi: 10.5772/intechopen.77843.

[6] A. G. Gilbert,Alan, Josef Gugler, 1992,Cities, Poverty, a Development: Urbanization in the Third World, Oxford University Press.

[7] $\mathrm{ADB}$ and A. D. B. (ADB), City development strategies to reduce poverty. Manila: Asian Development Bank, P.O. Box 789, 0980 Manila, Philippines, 2004.

[8] S. V. \& N. M. IDA GABRIELSSON, "Commentary/Building resilience one mangrove forest 
at a time," rethink.earth, 2018. .

[9] S. S. Noni HD, Suharyanto, "Partisipasi Masyarakat dalam Perencanaan Sabuk Hijau pada Kawasan Waduk Jatibarang, Semarang." 2012.

[10] N. Noegroho and Y. M. Ardiani, "Utilization of greenbelt zone around the dam Study case: Logung Dam, Kudus Regency, Central Java,” IOP Conf. Ser. Earth Environ. Sci., vol. 195, no. 1, 2018, doi: 10.1088/1755-1315/195/1/012084.

[11] R. Shi, "Ecological environment problems of the Three Gorges Reservoir Area and countermeasures," Procedia Environ. Sci., vol. 10, no. PART B, pp. 1431-1434, 2011, doi: 10.1016/j.proenv.2011.09.228.

[12] B. Taylor, "Kenya's green belt movement: Contributions, conflict, contradictions, and complications in a prominent environmental non-governmental organization (ENGO)," Civ. Soc. Age Monit. Democr., vol. 7, no. July 2013, pp. 180-207, 2013.

[13] dan E. S. Singarimbun, M., Metode Penelitian Survei. Jakarta: Gramedia Pustaka Utama, 1995.

[14] B. Mikkelsen, Britha Helene, 1995, Methods for Development Work and Research: A Guide for Practitioners, SAGE Publications Pvt. Ltd.

[15] N. Muhadjir, Metodologi Penelitian Kualitatif. Yogyakarta: Rake Sarasin, 2000. 